\title{
Undivided Corporate Responsibility: Towards a Theory of Corporate Integrity Thomas Maak
}

\begin{abstract}
In the years since Enron corporate social responsibility, or "CSR," has become a ubiquitous phenomenon in both research and business practice. CSR is used as an umbrella term to describe much of what is done in terms of ethics-related activities in firms around the globe to such an extent that some consider it a "tortured concept" (Godfrey and Hatch 2007, Journal of Business Ethics 70, 87-98). Addressing this skepticism, I argue in this article that the focus on CSR is indeed problematic for three main reasons: (1) the term carries a lot of historical baggage - baggage that is not necessarily conducive to the clarity of the concept; (2) it is the object of increasing ethical instrumentalism; and (3) given the multiple ethical challenges that corporations face, and given the fact that the "social" responsibilities of business are but one set of corporate responsibilities, a suitable term would have to be more inclusive and integrative. I therefore suggests moving instead toward a sound definition of corporate integrity and aim in this article to develop a working definition by fleshing out "7 Cs" of integrity: commitment, conduct, content, context, consistency, coherence, and continuity. I then discuss how these 7 Cs impact our understanding of CSR or, more broadly, corporate responsibility in general.
\end{abstract}

Dr. Thomas Maak is Research Director at the Institute for Business Ethics and Reader in Corporate Responsibility at the University of St. Gallen (Switzerland) and Visiting Senior Research Fellow at INSEAD, France, where he codirects a research stream on "Developing responsible leadership for sustainable business" within the PwC-INSEAD initiative on high-performing organizations. He earned his PhD in Business Ethics, Summa Cum Laude, from the University of St. Gallen and held visiting appointments at Columbia University and Georgetown University. Currently, he is a member of the executive committee of the European Business Ethics Network EBEN. Among his many publications is the recent "Responsible Leadership," published by Routledge in 2006.
KEY WORDS: integrity, corporate integrity, corporate social responsibility

\section{Introduction}

The corporate scandals in recent years have triggered a broad discussion on the role of business in society, that is to say, on its legitimacy, obligations and responsibilities. As a result, there has been an exponential increase in corporate social responsibility (CSR) activities and reporting (for current data see e.g., www.corporateregister.com). Responding to their constituencies corporations have started to present themselves in much detail as "good corporate citizens," explaining why and how they care about a sustainable future and what they do for their employees, both at home and abroad. And while there has long been disagreement about the proper role of business organizations in society (Brickson, 2007), there is arguably a heightened public awareness and scrutiny by critical stakeholders as to how corporations run their businesses and what constitutes legitimate business behavior. In fact, "CSR" has become a ubiquitous phenomenon in both research and business practice. It is used as an umbrella term to describe much of what is happening in terms of ethics-related activities in firms around the globe (Scherer and Palazzo, 2007) to such an extent that some consider it a "tortured concept" (Godfrey and Hatch, 2007), a label depicting everything and nothing. At the same time, however, a body of serious academic literature has emerged (Margolis and Walsh, 2003), exploring new avenues of research, such as organizational identity (Brickson, 2005, 2007), sense making processes (Basu and Palazzo, 2008), institutional mechanisms (Campbell, 2007), or the political role of the corporation (Scherer and Palazzo, 2007) in order to better understand the CSR phenomenon. 
The skepticism vis-à-vis CSR as opposed to related concepts such as business ethics, corporate social performance, or stakeholder theory may be due to its long and varied history and to the fact that many scholars, in particular in Europe, perceive it as either too narrow a concept, blurred, or even too "American," for that matter. In addition, it has been endorsed by business practice to connote responsible behavior in increasingly instrumental ways. I will touch on each of these reasons and present my own reasoning why "CSR" might indeed become a 'cul-de-sac': I argue in what follows that the focus on CSR is indeed problematic for three main reasons: (1) the term carries a lot of historical baggage baggage that is not conducive to the clarity of the concept; (2) it is the object of increasing ethical instrumentalism and hypocrisy; and (3) given the multiple ethical challenges that corporations face, and given the fact that the "social" responsibilities of business are but one set of corporate responsibilities, a suitable term would arguably have to be more inclusive and integrative. I therefore suggest moving beyond the CSR label toward a sound definition of corporate integrity. My aim is to develop a working definition of corporate integrity by fleshing out the "7 Cs" of integrity: commitment, conduct, content, context, consistency, coherence, and continuity. I then discuss how these $7 \mathrm{Cs}$ impact our understanding of CSR or, more broadly, corporate responsibility, and conclude this article by reflecting on the undivided corporate self.

\section{From "SR to SCR": A short history of CSR as we know it}

The beginning of the debate on CSR is marked by a landmark study commissioned by the Federal Council of Churches of Christ in America, entitled "The social responsibilities of the businessman" (1953) and authored by Howard Bowen. Yet, 2 years earlier, in May 1951, Frank Abrams, a top executive with Standard Oil, published a remarkable piece of reflection on "Management's Responsibilities in Complex World" in the Harvard Business Review, a title that seems even more topical today than almost 60 years ago. Abrams urged his fellow managers, i.e., businessmen, to think of themselves as professionals with an explicit sense of duty not just to shareholders, employees, and customers, but also to the public in general: "(Modern) management must understand that the general public - men and women everywhere - have a very deep interest in, and are affected by, what is going on" (p. 32). He thus introduces an early stakeholder perspective. Bowen's study, in contrast, is concerned with detailing the specific social responsibilities of businessmen. He argues that businessmen must assume "a large measure of responsibility if the economic system of free enterprise is to continue and prosper" (1953, p. 5), appealing to enlightened self-interest. And although Bowen addresses questions such as "What constitutes good citizenship for a business enterprise? How does a moral enterprise behave?", or, "What kinds of business decisions promote the end of modern society and what kinds detract?" his and Abrams' early contributions focus on the responsibilities of individuals within an enterprise or corporation. Thus, in hindsight the beginning of CSR is in fact marked by a discussion on individual responsibilities of managers vis-à-vis their constituencies and society in general. Put differently, CSR was more like "SR" - social responsibility - and inextricably bound up with the responsibilities of executives.

It was not until the 1960s, however, that academia took serious notice of the emerging interest in CSR and the level of analysis still continues to be focused predominantly on the individual manager, or "businessman" for that matter (as there were hardly any women in leadership positions). Davis, e.g., refers to social responsibility as "businessmen's decisions and actions taken for reasons at least partially beyond the firm's direct economic or technical interest" (1960, p. 70); and argues that "the substance of social responsibility arises from the concern for the ethical consequences of one's acts as they might affect the interests of others." (1967, p. 46). The social and political revolution of the late 1960s, in particular rising social awareness and ecological concerns, triggered an intensification of the debate throughout the 1970s. It is Milton Friedman's piece on CSR (1970), which first appeared in the New York Times Magazine, that arguably had the most sustainable impact. Friedman famously claimed "that the social responsibility of business is to increase its profits" (and nothing else). He argues that businesses and corporations have in fact no 
responsibilities (p. 51), ${ }^{1}$ in contrast to a corporate executive (i.e., the individual). As a business person and "an agent serving the interests of his principal" (p. 53) the executive has direct responsibility to the principal (also called owner, employer, stockholder), namely "to conduct business in accordance with their desires, which generally will be to make as much money as possible while conforming to the basic rules of the society, both those embodied in law and those embodied in ethical custom." (p. 51). Yet, as Friedman points out, the executive is expected to comply with formal responsibilities and act in accordance with legal and moral standards in society. Friedman's much cited argument also marks a key reference for the latest resistance against "too much" CSR in terms of redistribution of profits which "are not the managers' to give away" (Crook, 2005, pp. 17, 18).

But the 1970s are also marked by serious attempts to define CSR more broadly. The Committee for Economic Development (1971) e.g., came up with a multi-level perspective: the inner circle consisting of a corporation's basic economic responsibilities, the middle level of "current social and environmental concerns" and the outer circle of "emerging responsibilities". Moreover, CSR is defined as "enlightened self-interest" (Steiner, 1971), as what goes beyond obeying the law in terms of "what every good citizen does..." (Davis, 1973), that is we find references to "good corporate citizenship." Eels and Walton (1974) define it as "concerns with the needs and goals of society," but we also find multiple references to the "legal responsibility" of a corporation, to "being ethical," doing charitable action, or ensuring legitimacy. Finally, the 1970s are marked by an increasing interest in the actual social performance of corporations (CSP) (Carroll, 1979; Sethi, 1975).

It was in the 1980s that the discussion on CSR became at once more diverse and more theoretical: scholars inquired about corporate responsibility in more general, i.e., ethical terms and attempted to define the moral status of the corporation. It was asked, "Can we hold corporations morally accountable for what they do? And if yes, does this require treating them as moral persons?" After all, our moral categories are designed by human individuals for human individuals. Therefore, can we or should we apply these moral categories to "corpo- rate organizations and their 'acts'?" (Velasquez, 2002, p. 17) The discussion around corporate moral agency (Donaldson, 1982; French, 1984; Velasquez, 1983) marked in some ways the emergence of business ethics as an academic discipline. It became clear that corporations can indeed be considered moral agents, because they have specific intentions and decision structures and thus the capacity to engage in moral decision making, to control their policies, rules, and actions and even to respond to ethical criticism, e.g., by external stakeholders. (Donaldson, 1982; French, 1995) Consequently, at the same time stakeholder theory was developed and put forward (Freeman, 1984). Moreover, Europe enters the discussion - a discussion that is propelled by "dark cases" like Bhopal (Union Carbide) and Exxon Valdez; the European Business Ethics Network EBEN is founded in 1987 and, last but not certainly not least, this journal, the Journal of Business Ethics, begins its influential work.

The 1990s bring further specialization and first business ethics theories: global warming and environmental concerns shift attention to issues of sustainable development and beyond mere social toward "triple bottom line"-performance (Elkington, 1998); the speed and scope of market globalization lead to increasing concerns about global business ethics (De George, 1993; Donaldson, 1989; Maak and Lunau, 1998). Moreover, Donaldson and Dunfee put forward an "Integrative Social Contract Theory" (ISCT, 1994; 1999), Ulrich (1997/2008) an "Integrative Business Ethics", Bowie (1998) "A Kantian Perspective" on business ethics, and the late Bob Solomon an Aristotelian, i.e., "Virtue Ethics Perspective" (1993, 1999).

Frederick (1998) divided the first 50 or so years of CSR into four phases: CSR 1 (1960s/1970s) as "doing the right thing"; CSR 2 (1980s), according to Frederick, is marked by more responsive corporate behavior toward social responsibilities, i.e., "corporate social responsiveness"; CSR 3 (1990s) is marked by compliance and Frederick imagines that CSR 4 (since then) will bring more focus on cosmological and spiritual aspects. It remains to be seen whether or not CSR will indeed become more holistic in nature. As it stands, it is a stretched out construct - maybe not a "tortured" one, but certainly hard to pinpoint. It took Archie Carroll (1999) e.g., almost 30 pages to revisit 50 years of CSR and 
provide an evolutionary perspective of a "definitional construct."

Interestingly enough, throughout much of the 1980s and 1990s, we find little mention of CSR, or new CSR theories for that matter. As sketched out above, we witness specialization and diversification toward other field of interests. This, however, changed with Enron. Ever since the fallout of Enron and the subsequent discussion as to what should be done to prevent another Enron from happening, i.e., with the beginning of this millennium, CSR became the key term and focus of attention. This perhaps, because it appealed (and appeals) to increasingly concerned practitioners as a handy-to-use term, free from moralizing about the proper role of business and free from ethical "heavy-lifting" which by nature dominates the academic discourse in business ethics; or, maybe because it was early on institutionalized in fora such as "CSR Europe" and was a term already in use in many firms. But, it is perhaps also, I would argue, because it developed into "SCR" - strategic corporate responsibility.

By "strategic corporate responsibility" I wish to connote the increasingly instrumental use of CSR as a strategic positioning device in the post-Enron environment. In order to succeed in an environment of contested values (Diermeier, 2006) CSR is "used" for reputational gains; CSR strategy in and of corporations is seen as a means to gain competitive advantage on "the market for virtue" (Vogel, 2006). Not surprisingly, the number of (more or less glossy) CSR reports has risen exponentially in recent years, ${ }^{2}$ demonstrating just how responsible corporations behave and that they should be trusted as good citizens around the world. I do not mean to imply that what gets published in these reports is without substance. On the contrary, there are many corporations which take the CSR challenge very seriously, that is as a challenge to their ethical legitimacy and try to act, and react, accordingly. Yet, the way CSR has been transformed into "SCR" since the beginning of the millennium leaves the door wide open for moral hypocrisy (Bateson et al., 2006), i.e., it may motivate corporations to appear moral (by way of CSR) without bearing the costs (and consequences) of actually being moral. In other words, if CSR deteriorates to mere PR then it becomes shallow and ultimately a useless concept - at least in ethical terms. Practically speaking, CSR is instrumentalized to benefit the corporation; theoretically speaking, as "instrumental theory" (Donaldson and Preston, 1995), it sets out to describe what will happen if a firm uses CSR as a strategic tool. Thus, CSR as strategic corporate responsibility ranges from risk and reputation management (Fombrun, 1996; Jackson, 2004) and measures to enhance client focus and benefits (Kotler and Lee, 2005) to initiatives in which "social and business benefits are large and distinctive" (Porter and Kramer, 2006). Consequently, Burke and Logsdon (1996, p. 496) define CSR as strategic "when it yields substantial business-related benefits to the firm." Moreover, Porter and Kramer (2006) as leading proponents of instrumental theory argue that "the essential test that should guide CSR is not whether a cause is worthy but whether it presents an opportunity to create shared value" (p. 84). Consequently, corporations should engage in "truly strategic CSR"; "it's about choosing a unique position - doing things differently from competitors..." (2006, p. 88). In other words, CSR is no longer considered a social or even a moral obligation of a corporation to society at large, but a mere market opportunity to achieve competitive advantage.

\section{Moving beyond CSR}

To recapitulate, so far I have presented arguments to support two main reasons why CSR may be an increasingly ill-fitted term to connote the responsibilities of corporations. One, given the long and varied history of CSR, as laid out above, the term does not and cannot represent more than a rather vague "umbrella term" for ethics-related issues in corporations and the connected academic disciplines: corporate social responsibility and performance, business ethics, corporate citizenship, stakeholder theory, and even sustainability. As such, it is the object of justified criticism from scholars in these disciplines and arguably too narrow a label to be used. If applied, it seems appropriate to connote the social responsibilities of businesses and executives. In this sense, early conceptualizations were more concise than the current use of the term. Two, as a result of being instrumentalized in terms of "strategic CSR," or "SCR," it may develop into mere ethical instrumentalism and thus - from an ethical point of 
view - be the object of skepticism and rejection. Either way, "CSR" seems ill-fitted to serve as an "umbrella term."

There is a third reason still to be considered and it ties into the diversification of what started out as CSR into academic disciplines: business ethics, stakeholder theory, etc. I would argue that the emergence of these fields of interest and ultimately disciplines in their own right is a reflection of an increasingly complex market environment and the challenges it entails - today more so than in the past. Corporations are faced with social, environmental, ethical, humanitarian, and political challenges - and they need to define who their stakeholders are and how to assess their claims. There is a widespread agreement that the stakeholder framework has proved useful in the analysis of the strategic and normative challenges organizations face and that good stakeholder relationships are key to organizational viability and success (Donaldson and Preston, 1995; Freeman, 1984; Post et al., 2002; Wheeler and Sillanpäa, 1997). Still, there remain both theoretical and practical challenges with respect to stakeholder salience (Jones et al., 2007; Mitchell et al. 1997), and to evaluate and balance conflicting claims of multiple stakeholders. Moreover, in a global stakeholder society moral dilemmas are almost inevitable and this raises questions on how to solve or even reconcile them. E.g., how can one adhere to basic moral principles while respecting cultural differences and different developmental standards? (De George, 1993; Donaldson, 1996). What needs to be done to secure 'uncompromising integrity' (Moorthy et al., 1998) on a global level, while leaving leeway for discretion in matters of particular corporate values and culture-specific decision making? In meeting these and related moral challenges, firms have to make sure that their actions are ethically sound, e.g., by reconciling cross-cultural dilemmas and knowing when different is different and when different is simply wrong (Donaldson, 1996). Moreover, balancing different stakeholder claims, including those of the natural environment, future generations and less privileged groups 'at the bottom of the pyramid' (Prahalad, 2005) creates social, environmental, and humanitarian challenges. While many corporations have adopted a 'triple bottom line'-approach (Elkington, 1998) and have started to integrate social and environmental considerations into their values creation, few have yet taken on humanitarian challenges such as poverty, hunger, or diseases. These miseries still prevent large parts of the human community from participating in the global economy, let alone benefiting from it. The actual challenge at hand is twofold - on the one hand to ensure active global corporate citizenship, meeting the political challenges inherent to the 21 st century corporation; on the other hand to actively engage in less privileged regions of the world by building and supporting human capabilities (Nussbaum and Sen, 1993) and by assisting in eradicating world poverty.

All considered, these challenges are not just practical challenges to be faced, but also the object of intensive academic debate and find their reflection in particular theoretical streams and disciplines: business ethics in general, as an established form of applied ethics, is concerned with systematic reflection on moral challenges in the business world; sustainability research elaborates on the environmental challenges businesses face; research on corporate citizenship or on "global business citizenship" (Wood et al., 2006) is concerned with the role of the corporation as a political actor (Scherer and Palazzo, 2007) and thus the political challenges in today's market environment; CSR research in more specific terms, that is, in its original sense, deals with social challenges in business; and recently emerging research on "business as an agent of world benefit" (BAWB, 2006) and "business solutions to poverty" (Lodge and Wilson, 2006; Prahalad, 2005; Rangan et al., 2007) is focusing on the humanitarian challenges and proposing solutions as to how poverty could be eliminated.

Given the scope and diversity of all these challenges and the richness of research domains a proper "umbrella term" would certainly need to be more inclusive, integrative and holistic than the CSR label. Obviously, CSR is but one important domain among multiple domains of interest and relevance. Yet, given that these domains are connected to each other, that all of them deal with ethical challenges in business, broadly defined, that in fact meeting these challenges requires some kind of integration work, we suggest using corporate integrity as an umbrella term instead. Still, since there are "many faces of integrity" as Audi and Murphy (2006) argue, and since both integrity and corporate integrity are far from being well defined, we need to establish a more 
profound conceptual basis in order to support our choice of terms. I will do so by clarifying, firstly, the meaning of integrity and thus the different "faces" and levels of integrity, and secondly, by fleshing out in more detail the 7 Cs of corporate integrity.

\section{Integrity}

According to Webster's New World Dictionary integrity means "the quality or state of being complete; unbroken condition; wholeness; entirety," and "the quality or state of being of sound moral principle; uprightness, honesty, and sincerity." Indeed, both meanings correspond with our common perception and understanding of the term. The first thought that comes to our mind usually relates to a person of integrity: someone has integrity if she acts in accordance with important moral principles, does so in a coherent and consistent way, over time, i.e., on an ongoing basis, especially when the going gets rough. "Integrity involves fidelity to one's endorsements" (Calhoun, 1995, p. 244), all important endorsements, i.e., or it would not be integrity - an unbroken commitment to uphold a recognizable set of moral principles (McFall, 1987, p. 15). What is obvious from this meaning of integrity - as moral integrity - is that wholeness, entirety, an unbroken condition are part of it. Thus, the idea of wholeness, of being complete, is an essential ingredient of moral integrity.

The notion of integrity, then, implies a state of being "undivided", an integral whole in the basic sense "of being of sound moral principle." In order to achieve this state, however, certain requirements have to be met: First, "being of sound moral principles" obviously requires a commitment to some desirable moral principles such as honesty, respect, or sincerity. Yet, these principles cannot be just some principles - principles which I value highly, e.g., but need to be the right principles (Calhoun, 1995, p. 248), or they would not be desirable or recognizable by others. And, "we expect persons of integrity not only to stand up for their most deeply held and highly endorsed commitments, but to treat all of their endorsements as ones worthy of being held by a reflective agent" (ibid, p. 245). Remember, "wholeness" and "being undivided" are essential for the achievement of integrity. Thus, the element of commitment alone is already full of requirements: persons of integrity need to commit themselves to the right moral principles. This commitment is not just some internal state but is evaluated by others; i.e., integrity is ascribed and therefore, despite being a unique individual state, a relational phenomenon. Moreover, commitment implies that a "person of integrity is willing to bear the consequences of her convictions, even when this is difficult, that is, when the consequences are unpleasant" (McFall, 1987, p. 9). In other words, if upholding moral principles gets tough, if it demands concessions or gets costly, it is still required that I act in compliance with these principles, given that acting morally can reasonably be expected of me. Integrity, "standing for something" (Calhoun, 1995), implies unconditional commitment (McFall, 1987, p. 11) to do the right thing and to do things right; whether it suits me or not, or whether it pays or not, is irrelevant.

Second, and with respect to doing the right thing, integrity requires responsible action or, in other words, moral conduct in line with my integrity requirements; e.g., by acting in a socially and environmentally responsible manner, by fulfilling my political obligations, and so on. Thus, thirdly, it is not only important that I act responsibly, but also what I do in terms of content-related requirements is equally relevant. Fourth, given that integrity is a relational phenomenon, it is not only at stake in relation to some constituencies, say to friends or shareholders, but in relation to all stakeholders. Integrity ascription, although predominantly happening in close(r) relationships, depends on consistent integrity views of all relevant others, that is, all those with whom I have a (more or less) regular relationship. As Brown puts it, "for individuals to have real integrity they must be conscious of the relationships in which they live." (2005, p. 6). And, from an organizational point of view, we may add that integrity "is one of the key life-sustaining properties in the relational nature of organizational existence" (Srivastva et al., 1988, p. 5).

Fifth, and connected to both commitment and conduct, integrity requires consistency of words and deeds. It demands that we adhere in consistent ways to ethical principles by aligning what we do and what we say (Brown, 2005, p. 5). In other words, a person (or a corporation) is ascribed integrity only if 
others have reason enough to believe that what this person (or corporation) does (and says) is credible and authentic - if she does what she says and talks openly and honestly about what she does: integrity requires walking the talk.

Moreover, sixth, a key property of integrity is clearly coherence of principles and action. In fact, most definitions would probably list coherence as integrity's main feature as it connotes the state of being "undivided" most accurately and with respect to at least two main directions: firstly, as mentioned already, coherence between (moral) principle and (moral) action is of paramount importance. To give an example: to value and respect basic human rights, such as the right not be harmed, implies that one does so irrespective of the conditions, be they favorable or unfavorable, i.e., unconditionally. Let us say, I intend to do business in a South-Asian country that does not have democracy yet; say, for argument's sake, that this would require me to work with "state-controlled" suppliers who have been known in the past to have violated human rights repeatedly; in order to ensure my integrity I would have two basic options: one, to convince these suppliers not to harm any of their workers anymore and ensure their compliance; and two, to pull out of that country. In any case, integrity requires "sticking to one's principles", moral or otherwise (McFall, 1987 , p. 7), whatever business opportunity may come along.

Secondly, coherence also implies the alignment of internal and external coherence. Internal coherence describes according to McFall $(1987$, p. 8) the way in which one's principles are held, how one may act given these principles, but also how one may be motivated in acting on them. In other words, to guard one's integrity requires not just doing the right thing in line with basic moral principles to which one has subscribed; internal coherence is only given if the agent does so for the right reasons, i.e., with the right intention. Thus, if I prevent human rights violations just because NGOs watch over what I do and because it is expected by society and serves my reputation, if I engage in responsible behavior just because it (currently) pays, I compromise my integrity. This may not be obvious to others, at least not right away; yet, it undermines my integrity nonetheless and may lead eventually to a loss of reputation. Call this the inner condition of integrity or simply good character requirement. External coherence on the other hand connotes the visible part of behavior ensuring integrity. It comprises, from a conceptual point of view, what others demand from me in terms of getting my principles and my action right: that I follow the right principles, do what is worth doing, consistently and in relations to all my constituencies, even "when the consequences are unpleasant" (McFall, 1987, p. 9). In sum, integrity or wholeness "has as much to do with one's coherent connections and relationships with other people and institutions as it does with one's relation to oneself." (Solomon, 1999, p. 39).

And finally, seventh, integrity requires continuity. We may, e.g., applaud the whistleblower who shows moral courage in making public what ultimately are symptoms and outcomes of an ethically deficient organization. The whistleblower may have tried to stop the organization from ethical wrong-doing but - as an isolated upright organization citizen - could not succeed. Putting oneself on the line to guard what is (morally) right usually takes not only a lot of courage, but may even have unpleasant consequences, such as mobbing and exclusion. Now, does all this mean that the whistleblower is a person of integrity? Not necessarily; he may have taken the step in order to become a person in the spotlight. My point is, to ascribe integrity to a person requires that we have known this person over a certain period of time so that we could observe if she acted "with integrity," or more precisely, in line with integrity requirements. Such continuity, in particular when the going gets rough and the person has mastered "integrity tests," is a necessary element of integrity.

All considered, integrity is obviously more than just a preferable virtue among others. Audi and Murphy (2006) have argued that integrity should be considered an "adjunctive virtue" rather than a substantive virtue in its own right. It is "adjunctive" in the sense that it integrates several desirable moral qualities. While I agree with the authors that integrity differs from virtues like, say, benevolence or honesty, by being less concise, or "substantive"; "adjunctive" seems far too weak a term to describe integrity as laid out above. Rather, I agree with Bob Solomon, who contends that integrity "is not in itself so much a virtue as it is a synthesis of the virtues" (1999, p. 38). Thus, to call it a "super" or 
"master virtue," aimed at ensuring unified moral agency, moral integration and ultimately an undivided moral self, reflects better what it stands for and what is at stake. It also ties into the conclusion that both McFall (1987) and Calhoun (1995) draw from their in-depth inquiry into the nature of integrity. McFall argues that integrity is in fact "a personal virtue granted with social strings attached" (p. 11), highlighting the social and ascriptive nature of integrity; Calhoun takes her argument a step further by stating that it is both a social trait and a social virtue - indicating the social nature of integrity.

To summarize, all of the above conditions commitment, conduct, content, context, consistency, coherence, and continuity - need to be met and aligned to ensure integrity. Thus, integrity obviously requires integration, active moral agency. Complex as it may be, to master integrity requires integrative efforts to ensure alignment of intention and purpose (commitment), conduct, responsibilities (content), relationships both distant and close (context), words and deeds (consistency), principles and action as well as internal and external conditions (coherence), on an ongoing, life-long basis (continuity). Yet, the relational nature of integrity is such that despite one's continuing efforts to achieve this state of wholeness, it remains difficult as "one's integrity is implicated in everything one does" (Calhoun, 1995, p. 242).

\section{Toward a theory of corporate integrity}

Until now, in defining the "7 Cs" of integrity, my level of analysis was pre-dominantly the individual person. However, my aim in this article is to flesh out in more detail a working definition of corporate integrity. This raises the question "Can we apply the same conditions and integrity requirements to corporations and individuals?" The answer is yes, for the following reasons: one, as argued above, the discussion on corporate moral agency (Donaldson, 1982; French, 1984; Velasquez, 1983) made clear that corporations can indeed be considered moral agents because they have specific intentions and decision structures and thus the capacity to engage in moral decision-making, to control their policies, rules, and actions as well as to respond to ethical criticism, e.g., by external stakeholders (Donaldson,
1982; French, 1995). Therefore, as Moore (1999, p. 339) notes, the acceptance of corporate "moral agency" is not only plausible but in fact is a reflection of 'reality'. Moreover, Velasquez argues that "it makes perfectly good sense to say that a corporate organization has moral duties and that it is morally responsible for its acts" (2002, p. 18), if only in a secondary sense, with individual decision makers as primary moral agents. Thus, given the widespread agreement that there is in fact corporate moral agency and given the complex demands of ensuring integrity it is only logical to work out a notion of corporate integrity. Two, the multiple ethical challenges of today's corporation require integration, i.e., concerted efforts to align corporate principles and practice, to engage stakeholders, to ensure ethically sound issue management and certainly also to align words and deeds. In other words, they require integrity. And three, even if we took just the non-moral sense of the word - "wholeness," i.e., if we left out the moral requirements of integrity, the term "corporate integrity" could still be employed, at least in a metaphorical sense.

Moreover, the term has been used occasionally in recent years: Audi and Murphy (2006) give an overview of the many uses of the term "integrity," including references in discussions on business ethics, although without special mention of the corporate level. Still, they note that the term "is quite possibly the most commonly cited morally desirable trait" in the world of business; "but integrity is used in widely differing ways..." (p. 3). However, in light of these many uses they are more concerned with defining its character as an "adjunctive virtue," not with its meaning in corporate terms. Bob Solomon (1999) has given it, as already mentioned, a prominent role as a "synthesis of the virtues." Yet, his Aristotelian business ethics approach is naturally centered on the individual and thus more concerned - as one book title suggests - with the question "how personal integrity leads to corporate success." Srivastva et al. (1988) highlighted early on the significance of "executive integrity," as did Watson (1991) by presenting insights from America's CEOs. Becker (1998) inquired into the role of integrity in organizations in search of an "objective code of morality" while Petrick and Quinn (2001) have focused on leadership integrity as a "strategic asset." Koehn (2005) shared their intuition by arguing that 
integrity in general, properly understood, could function as a "business asset." What all these sources have in common is their more or less explicit focus on individual integrity and its relevance in the world of business.

The actual idea of organizational or corporate integrity was first put forward explicitly by Paine (1994). She contrasted the pre-dominant compliance focus in (American) business ethics with an integrity perspective and sketched out key features of an "integrity strategy" as a way of pro-active assurance of responsible conduct, in contrast to a legally driven, reactive compliance focus. Among other sources are Thorne LeClair et al. (1998); they however mix both by offering a "blueprint for compliance" as "integrity management". An explicit integrity management system is at the core of Kapteins (1999, 2003) and Kaptein and Wempes (2002) contributions. Similarly, Kennedy-Glans and Schulz (2005) provide an "integrity toolkit." Yet, while all these contributions underscore the significance of corporate integrity, they miss out on one important element, namely providing a sound definition of corporate integrity that pays tribute to both the moral and the holistic meaning of the term in light of the ethical challenges in and around organizations. Paine has certainly popularized the term but her focus is on aligning ethics and strategy, not on integrity as wholeness; and Kaptein and Wempe (2002) should be given credit for highlighting the importance of aligning principles and action by way of "integrity management." Yet, their first chapter is entitled "Why business ethics?", i.e., although integrity is a focus of their inquiries, their main focus is on business ethics in general and management tools in particular (Kaptein, 1999, 2003), not on a particular theory of corporate integrity. Thus, while these authors have prepared the path toward integrity, I argue here that we can follow that path properly and successfully - and achieve true integrity (morally and holistically) - only if we establish a sound understanding of corporate integrity in its own right.

Brown (2005) has come close to doing so by suggesting that corporate integrity consists of five dimensions: a cultural dimension in terms of openness and inclusive behavior, an interpersonal dimension depicting "relational wholeness," organizational integrity "as pursuing a worthwhile purpose," "social integrity as civic cooperation," and ultimately natural or environmental integrity as "natural prosperity," with leadership as the integrative force. Thus, he emphasizes commitment ("worthwhile purpose"), content (social and environmental issues) and context of corporate integrity ("relational wholeness"). However, while he advances our understanding regarding corporate integrity he mixes conceptual and content related issues, i.e., loci of morality and issues of morality, and therefore fails to provide a consistent and coherent definition of corporate integrity.

But still, his approach illustrates that in seeking to ensure integrity in business we are confronted with different levels of integrity: the level of the individual person and thus individual integrity - I refrain from calling it "executive integrity" (Srivastva et al., 1988) because it ought to include all individuals, executives and employees alike; the level of the organization and thus corporate integrity, but also the level of stakeholder integrity, broadly defined as the integrity of all individuals or groups who have a legitimate interest in, are affected by or could be affected by the activities of both the corporation and the members of the corporation (Freeman, 1984). These interacting but different levels of integrity create a particular "challenge of wholeness" (Kolb, 1988, p. 70): although these levels are not competing for their integrities, there may be instances when individual integrity and organizational integrity conflict with each other, e.g., in cases when ethical principles and profit motives collide, up to a point when the individual's last resort is to blow the whistle to save her own integrity. As for external stakeholders, this integrity tension might occur more frequently, given that they may value different things in life, expect the corporation to be less profit- and more community-oriented, etc. Moreover, in case of (doubtful) suppliers in developing countries who operate with production methods that are harmful to their workers (as it was the case with the sports apparel maker Nike), or use harmful substances (as in the case of the toymaker Mattel), supply chain integrity becomes a major challenge for the corporation in order to ensure its own corporate integrity. Thus, there is an obvious need to synchronize the integrities of all moral agents to the extent that they become conducive to each other and do not interfere with each other, e.g., by aligning individual and corporate principles, by aligning suppliers to one's own integrity requirements or by 


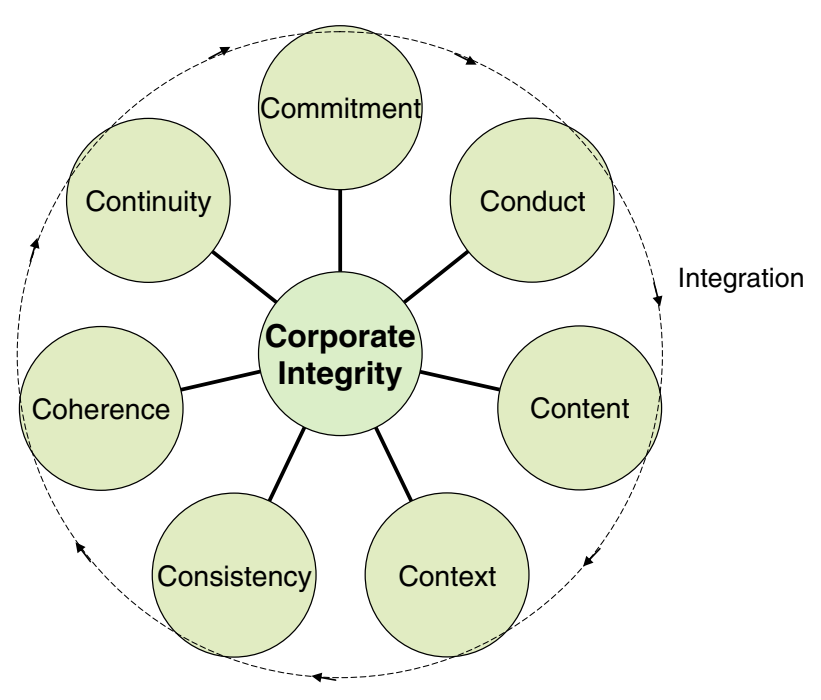

Figure 1. The 7 Cs of Corporate Integrity.

creating common ground and purposeful partnerships with critical stakeholders.

Figure 1 depicts the 7 Cs of corporate integrity in a circular way; the outer circle indicates the constant need for integration.

\section{Commitment}

As discussed above, commitment requires that the moral agent is committed to a "worthwhile purpose" (Brown, 2005) and important moral principles, i.e., not some principles or the company's own principles, but the right principles, even when "sticking to them" may get unpleasant. As a basic condition for corporate integrity this implies that the company's principles are aligned to the basic moral principles of society and basic human rights more generally. In a (global) stakeholder society the "rightness" of a company's principles is ultimately not determined by its management or shareholders but by the critical public in general; it is determined in public deliberation (Scherer and Palazzo, 2007). Moreover, in the light of growing stakeholder expectations with respect to the various responsibilities of corporations beyond its core economic purpose - social, environmental, civic, and humanitarian - it is essential that corporations make sure that their purpose is indeed considered worthwhile; not just by shareholders but by all stakeholders. Thus, with "values everywhere" (Diermeier, 2006, p. 156) and growing expectations to deliver on these values it becomes crucial for a corporation to show and prove its commitment to a worthwhile purpose and the "right" principles. The quest for corporate integrity, then, is at least to some extent an "ethics competition": corporations compete on having the right values and principles. Not surprisingly, we witness an exponential increase in CSR reporting. Yet, success, i.e., ascription of integrity, also depends on the uncompromising commitment to these basic principles. As discussed, integrity is not ascribed for having "sunshine ethics," e.g., supporting human rights when it does not implicate the economic bottom line, but for sticking to one's core principles even when it gets "costly," e.g., by pulling out of a country where human rights violations occur or by not going there in the first place, thereby foregoing “economic opportunities" but saving one's integrity.

\section{Conduct}

As noted above, integrity requires responsible action or, in other words, moral conduct in line with one's integrity requirements. It is with respect to responsible conduct that "integrity management" or "managing with integrity" comes into play. To ensure corporate integrity professional ways of designing, steering, and controlling integrity related matters in a corporation need to be implemented. With respect to wholeness (i.e., by definition) this management approach has to be holistic or it would not be integrity management. Thus, it requires thorough and systematic endeavors to find and close possible loopholes - integrity gaps - that could endanger the integrity of a corporation. Again, to give an example related to supply chain integrity: companies like Nike or Mattel have worked hard to build both their images and reputation. Yet, both have suffered considerably due to lapses in their particular supply chains: Nike, because their incentive system was not aligned with the company's commitment to social and human rights (Maak and Ulrich, 2007, p. 271); Mattel because they were apparently unable to ensure that their Chinese suppliers do not use harmful substances such as leadbased colors in the toy-making process. With outsourcing and a vastly progressing division of labor in the global economy companies like Nike and Mattel 
need to ensure that they close all potential integrity gaps. A company's integrity is not only implicated by everything it does, but also and more importantly by what it does not do. Each and every integrity gap can endanger corporate integrity as such - because it implicates "wholeness." It is therefore imperative that a corporation makes sure, e.g., by implementing an integrity management system (Kaptein, 1999; Kennedy-Glans and Schulz, 2005; Paine, 1994), that individual and corporate conduct are aligned, that it supports pro-active action to prevent any gaps from arising and that it has principles-based processes in place that ensure ethically sound behavior in all walks of corporate life.

\section{Content}

The third "C", content, connotes the fact that it is not only important that a corporation (or the individuals in that corporation) act responsibly, but also what it does. Coming back to the aforementioned ethics challenges, the "what" relates, broadly speaking, to social, environmental, civic and humanitarian values creation. Integrity requires both addressing these challenges and the inherent stakeholder expectations and fulfilling any corporate responsibilities derived from these challenges. "Standing for something" (Calhoun, 1995) in social terms means living up to the corporate social responsibilities and meeting certain basic social expectations of stakeholders and communities at large, e.g., by providing a safe and decent workplace and social benefits for employees, supporting life-work balance programs, enabling an inclusive work environment by respecting cultural differences, establishing kindergartens, etc.; but also by being socially responsive to the need of communities and society at large. In terms of the natural environment companies are arguably expected to be part of the solution to global warming and the environmental crisis, and not part of the problem. Thus, sustainability in processes and practices and the idea of environmental stewardship in principle become a focal point for corporate value-creation. Moreover, there is widespread agreement that corporations have civic obligations. Whether or not corporate citizenship is a mere metaphor or if it in fact represents the political status of the corporation is a different debate (see e.g., the BEQ issue 1/2008).
The fact is that corporations are part of communal life and they contribute to communities in which they operate and they are expected to act as "good global citizens," both at home and abroad. Lastly, as discussed in the beginning, there are growing expectations vis-à-vis larger, multinational corporations to assist and take on a more active role in fighting some of the world's most pressing public problems such as diseases (HIV Aids, etc.), poverty, and hunger. What we witness, then, are emerging humanitarian responsibilities. In addition, we should not forget to mention a corporation's basic economic responsibilities; all of which require integration work, alignment and an active, integrity-focused issue management. Today's corporations are expected to engage in multiple values-creation; and integrity ascription depends on how they deliver on what can reasonably be expected. Thus, it is not expected that they transform into social organizations; however, making profits is certainly not sufficient to ensure one's integrity.

\section{Context}

Context, as a basic condition for integrity, is well defined through "relational wholeness" (Brown, 2005 , p. v). Corporate integrity as a relational phenomenon requires engaging responsibly with, and responding to, all stakeholders. It is not only at stake in relation to some constituencies, but in relation to all constituencies. Therefore, just like individuals, for corporations to have true integrity they must be conscious of all relationships in which they participate, engage with all their constituencies in responsible ways, meet their reasonable expectations and be considered a partner (and not a burden) in ensuring a sustainable future. Practically speaking, what is required is an ethically sound stakeholder engagement and management; one that is not driven by instrumentalism (Jones, 1995), but takes it as a given to engage with others (i.e., internal and external stakeholders) irrespective of the beneficiality of such engagement, basing their commitment on mutual recognition and good reasons. "Relational wholeness" requires sound relating as well as being consciously embedded in one's whole range of relationships; internally, externally, and with societies at large (Maak and Pless, 2006b). 


\section{Consistency}

Moreover, corporate integrity requires consistency of words and deeds. It demands that a corporation adheres to ethical principles in consistent ways, in particular with respect to aligning talk and walk. Tying into integrity commitment this implies being honest and sincere about the corporation's CSR achievements, but also about its failures, and not using CSR reports as a "selling device" but as an instrument for authentic representation and stakeholder dialogue. A corporation is ascribed integrity only if stakeholders have reason enough to believe that what the corporation did, or does, and what it says is credible and authentic. Yet, authenticity is attributed only if both talk and walk are aligned and if over time no credibility gaps are detected (Maak and Ulrich, 2007, pp. 22, 122). Corporations need to be aware that windowdressing, even in small, unintended, PR-driven amounts, can be a serious threat to their integrity. Again, one's integrity is implicated by everything one does (Calhoun, 1995, p. 242); yet, it is already on the line, compromising all other efforts, if manipulation or even hypocrisy come into play. It should be noted, then, that keeping low profile is certainly a better "integrity strategy" than raising one's profile without substance (i.e., action) to support it.

\section{Coherence}

As for coherence between (moral) principles and (moral) action, we noted earlier that this is a fundamental integrity requirement. It is imperative that a corporation sticks to all the principles it is committed to, in particular to the ethical principles as laid down in the code of conduct, values or mission statement. It is expected that these principles are aligned to those of society, that they fulfill basic moral requirements and promote standards of common decency. Again, integrity requires a corporation to make sure that it subscribes not just to some principles it considers important, say to fairness and profit maximization, but to the right principles. In other words, integrity ascription depends on synchronizing, or rather balancing, of a company's purpose and society's principles. Moreover, it depends on coherent action, i.e., corporate conduct in line with the company's principles and thus with what it stands for.
To pick a well-known example: when James Burke, the former CEO of the U.S. health company Johnson \& Johnson, decided to pull all Tylenol bottles off the shelves in North America, although cases of poisoning seemed to be restricted to the greater Chicago area, it was not only an act of responsible leadership (Maak and Pless, 2006a), but in line with the company's principles. These state that customers, that is the health (and safety) of customers, come first and shareholders last. Thus, $\mathrm{J} \& \mathrm{~J}$ was acting with integrity. Giving in to economic considerations by restricting the recall to certain areas, not knowing if the health of all customers would be ensured, was simply never an option given the company's focus on values and integrity. Such coherent behavior, in particular in defining moments, demonstrates to stakeholders that a company is serious about its commitments to certain principles, that it goes out of its way to make sure that people and the organization stick to these principles and that "customer focus" means focusing on customers desires and needs, not on their money. As a consequence, trust and integrity ascription follow, certainly not right away, but over the course of time and in sustainable ways. Moreover, the Tylenol example also illustrates both external and internal coherence: as for external coherence, it could be argued that Burke and J\&J not only followed the right principles, did what was worth doing, consistently and in relations to their constituencies, but did so when the consequences were unpleasant (McFall, 1987, p. 9) by way of a costly recall. And in terms of internal coherence it should be noted that apparently they also did it for the right reasons, i.e., with the right intention. The rationale for the recall was not that more cases of poisoning may have damaged the company's image or even reputation, or the fear of costly lawsuits, but simply the conviction that the health of customers come first. To conclude, it does not suffice to do the right thing if others (i.e., stakeholders) take it to be happening for the wrong reasons.

\section{Continuity}

Lastly, corporate integrity cannot be achieved by seizing the moment. The ideal of unified moral agency implies a more or less explicit evaluation 
process by the agent's constituencies (i.e., stakeholders) over time. Stakeholders need to have sufficient reason to believe that the corporation and their executives take ethics seriously. This requires that the corporation has demonstrated an ongoing commitment to important principles, even in turbulent times; that it has consistently acted responsibly and in cases of lapses acted swiftly to clarify them and keep them from happening again; that it has done so in recognition of all its constituencies in good times and in bad times; that it has constantly tried to balance its multiple responsibilities - economic, social, environmental, civic, and humanitarian; and that it has never left a doubt that it has considered living up to these responsibilities to be simply the right thing to do.

\section{Conclusion: Overcoming the divided corporate self}

To conclude, I believe that a detailed account of corporate integrity as presented above advances our understanding with respect to how corporations should think about "CSR," namely in more holistic ways in order to capture the complex reality of corporate responsibility, broadly defined. In fleshing out the $7 \mathrm{Cs}$ of corporate integrity, I have demonstrated what is at stake in today's environment of contested values and that corporate integrity is not just another term to be used in CSR related or business ethics related matters. In contrast, it can serve as a sense making framework to further the integration of issues and levels. I argued that given the scope of ethics challenges it does not suffice to follow a piecemeal approach in matters of "CSR," or corporate responsibility in more general terms. Corporate integrity may raise the bar, but by aligning the various integrity requirements and by integrating issues and levels, corporations are arguably much better equipped to meet all and not just some of the ethics challenges and thus to act responsibly.

In regard to research, I am inclined to think that we have much to gain by employing corporate integrity as a sense making device. CSR, business ethics, stakeholder theory, corporate citizenship, etc. are all important research domains in their own right. Yet, what is still missing is a framework that connects these domains in plausible and workable ways. By working toward a theory of corporate integrity such "relational wholeness" may well be achieved. Thus, although I suggested that corporate integrity should be used as a more fitting "umbrella term" for corporate responsibility research in general and CSR in particular, it is certainly more than that, in terms of both research and practice. As for business practice, integrity is quite possibly the biggest asset a corporation can have. After all, as McFall puts it (1987, p. 20): "Without integrity, and the identity-conferring commitments it assumes, there would be nothing to fear the loss of, not because we are safe but because we have nothing to lose."

Thus, even though a focus on integrity raises the bar even further it is arguably the only chance to overcome an increasingly fractured corporate self. Meeting multiple stakeholder expectations, balancing their claims and realizing value for the many, and not just a few (managers and shareholders), requires an explicit sense of wholeness both in matters of relationships and in matters of content. I suggested in this article that a more explicit focus on corporate integrity may help in achieving this goal and ultimately becoming an "undivided corporate self."

\section{Notes}

1 The page references refer to a widely available reprint in Beauchamp and Bowie (2001).

2 See www.corporateregister.com for exact data.

\section{References}

Abrams, F. W.: 1951, 'Management's Responsibilities in a Complex World', Harvard Business Review 29(3), 29-34.

Audi, R. and P. E. Murphy: 2006, 'The Many Faces of Integrity', Business Ethics Quarterly 16(1), 3-21.

Basu, K. and G. Palazzo: 2008, 'Corporate Social Responsibility. A Process Model of Sensemaking', Academy of Management Review 33, 122-136.

Bateson, C. D., E. Collins and A. A. Powell: 2006, 'Doing Business After the Fall: The Virtue of Moral Hypocrisy', Journal of Business Ethics 66, 321-335.

BAWB: 2006, 'Business as an Agent of World Benefit', Conference at Case Western Reserve University with Academy of Management and UN Global Compact, October 24-26. 
Beauchamp, T. and N. E. Bowie (eds.): 2001, Ethical Theory and Business, 6th Edition (Prentice Hall, Upper Saddle River, NJ), pp. 51-55.

Becker, T. E.: 1998, 'Integrity in Organizations: Beyond Honesty and Conscientiousness', Academy of Management Review 23(1), 154-161.

Bowen, H. R.: 1953, The Social Responsibilities of the Businessman (Harper \& Brothers, New York, NY).

Bowie, N. E.: 1998, Business Ethics. A Kantian Perspective (Blackwell, Malden, MA/Oxford).

Brickson, S.: 2005, 'Organizational Identity Orientation: Making the Link Between Organizational Identity and Organizations' Relations with Stakeholders', Administrative Science Quarterly 50, 576-609.

Brickson, S.: 2007, 'Organizational Identity Orientation: The Genesis of the Role of the Firm and Distinct Forms of Social Value', Academy of Management Review 32(3), 864-888.

Brown, M. T.: 2005, Corporate Integrity (Cambridge University Press, Cambridge/New York, NY).

Burke, L. and J. M. Logsdon: 1996, 'How Corporate Social Responsibility Pays Off, Long Range Planning 29(4), 495-502.

Calhoun, C.: 1995, 'Standing for Something', Journal of Philosophy 92(5), 235-260.

Campbell, J. L.: 2007, 'Why Would Corporations Behave in Socially Responsible Ways? An Institutional Theory of Corporate Social Responsibility', Academy of Management Review 32(3), 946-967.

Carroll, A. B.: 1979, 'A Three-Dimensional Conceptual Model of Corporate Performance', Academy of Management Review 4(4), 497-505.

Carroll, A. B.: 1999, 'Corporate Social Responsibility. Evolution of a Definitional Construct', Business $\mathcal{E}$ Society 38(3), 268-295.

Committee for Economic Development: 1971, Social Responsibilities of Business Corporations (Author, New York).

Crook, C.: 2005, 'The Good Company: A Survey of Corporate Social Responsibility', The Economist 22, 3-18.

Davis, K.: 1960, 'Can Business Afford to Ignore Social Responsibilities?', California Management Review 2, 70-76.

Davis, K.: 1967, 'Understanding the Social Responsibility Puzzle', Business Horizons 10(4), 45-50.

Davis, K.: 1973, 'The Case for and Against Business Assumption of Social Responsibilities', Academy of Management Journal 16(2), 312-322.

De George, R. T.: 1993, Competing with Integrity in International Business (Oxford University Press, Oxford/New York).

Diermeier, D.: 2006, 'Leading in a World of Competing Values', in Th. Maak and N. M. Pless (eds.),
Responsible Leadership (Routledge, London, New York), pp. 155-169.

Donaldson, T.: 1982, Corporations \& Morality (Prentice Hall, Englewood Cliffs, NJ).

Donaldson, T.: 1989, The Ethics of International Business (Oxford University Press, New York/Oxford).

Donaldson, T.: 1996, 'Values in Tension: Ethics Away from Home', Harvard Business Review 74(5), 48-56.

Donaldson, T. and T. Dunfee: 1994, 'Toward a Unified Conception of Business Ethics: Integrative Social Contracts Theory', Academy of Management Review 19(2), 252-284.

Donaldson, T. and T. Dunfee: 1999, Ties That Bind. A Social Contracts Approach to Business Ethics (Harvard Business School Press, Boston, MA).

Donaldson, T. and L. E. Preston: 1995, 'The Stakeholder Theory of the Corporation: Concepts, Evidence, and Implications', Academy of Management Review 20(1), 65-91.

Eels, R. and C. Walton: 1974, Conceptual Foundations of Business, 3rd Edition (Irwin, Burr Ridge, IL).

Elkington, J.: 1998, Cannibals with Forks: The Triple Bottom Line of 21st Century Business (New Society Publishers, Gabriola Island, BC/Stony Creek, CT).

Fombrun, C. J.: 1996, Reputation. Realizing Value from the Corporate Image (Harvard Business School Press, Boston, MA).

Frederick, W. C.: 1998, 'Moving to CSR 4. What to Pack for the Trip', Business \& Society 37(1), 40-59.

Freeman, R. E.: 1984, Strategic Management: A Stakeholder Approach (Pitman Publishers, Boston).

French, P. A.: 1984, Collective and Corporate Responsibility (Columbia University Press, New York, NY).

French, P. A.: 1995, Corporate Ethics (Harcourt Brace, Fort Worth/Dallas, TX).

Friedman, M.: 1970, 'The Social Responsibility of Business is to Increase Profits', New York Times Magazine, September 13, 32-33, 122-126. [Reprinted in: Beauchamp, T. and N. E. Bowie (eds.), Ethical Theory and Business, 6th Edition (Prentice Hall, Upper Saddle River, NJ), pp. 51-55].

Godfrey, P. C. and N. W. Hatch: 2007, 'Researching Corporate Social Responsibility: An Agenda for the 21st Century', Journal of Business Ethics 70, 87-98.

Jackson, K. T.: 2004, Building Reputational Capital, Strategies for Integrity and Fair Play that Improve the Bottom Line (Oxford University Press, Oxford).

Jones, T. M.: 1995, 'Instrumental Stakeholder Theory: A Synthesis of Ethics and Economics', Academy of Management Review 20(2), 404-437.

Jones, T. M., W. Felps and G. Bigley: 2007, 'Ethical Theory and Stakeholder-Related Decisions: The Role 
of Stakeholder Culture', Academy of Management Review 32(1), 137-155.

Kaptein, M.: 1999, 'Integrity Management', European Management Journal 17(6), 625-634.

Kaptein, M.: 2003, 'The Diamond of Managerial Integrity', European Management Journal 21(1), 99-108.

Kaptein, M. and J. Wempe: 2002, The Balanced Company. $A$ Theory of Corporate Integrity (Oxford University Press, Oxford/New York).

Kennedy-Glans, D. and B. Schulz: 2005, Corporate Integrity. A Toolkit for Managing Beyond Compliance (John Wiley \& Sons Canada, Mississauga, ON).

Koehn, D.: 2005, “Integrity as a Business Asset', Journal of Business Ethics 58, 125-136.

Kolb, D. A.: 1988, "Integrity, Advanced Professional Development, and Learning', in S. Srivastva and Associates (eds.), 1988, Executive Integrity. The Search for High Human Values in Organizational Life (JosseyBass, San Francisco, CA/London), pp. 68-88.

Kotler, P. and N. Lee: 2005, Corporate Social Responsibility (John Wiley \& Sons, Hoboken, NJ).

Lodge, G. and C. Wilson: 2006, A Corporate Solution to Global Poverty (Princeton University Press, Princeton, NJ/Oxford).

Maak, Th. and Y. Lunau: 1998, Weltwirtschaftsethik [Global Business Ethics] (Haupt: Bern/Stuttgart/Vienna).

Maak, Th. and N. M. Pless (eds.): 2006, Responsible Leadership (Routledge, London/New York).

Maak, Th. and N. M. Pless: 2006, 'Responsible Leadership in a Stakeholder Society', Journal of Business Ethics 66, 99-115.

Maak, Th. and P. Ulrich: 2007, Integre Unternehmensführung. Ethisches Orientierungswissen für die Wirtschaftspraxis [Managing with Integrity] (Schäffer-Poeschel, Stuttgart).

Margolis, J. D. and J. P. Walsh: 2003, 'Misery Loves Companies: Rethinking Social Initiatives by Business', Administrative Science Quarterly 48, 268-305.

McFall, L.: 1987, 'Integrity', Ethics 98, 5-20.

Mitchell, R. K., B. R. Agle and D. J. Wood: 1997, 'Toward a Theory of Stakeholder Identification and Salience: Defining the Principle of Who and What Really Counts', Academy of Management Review 22(4), 853-886.

Moore, G.: 1999, 'Corporate Moral Agency: Review and Implications', Journal of Business Ethics 21, 329-343.

Moorthy, R. S., R. T. De George, T. Donaldson, W. J. Ellos, R. C. Solomon and R. B. Textor: 1998, Uncompromising Integrity: Motorola's Global Challenge (Motorola University Press, Schaumburg, IL).

Nussbaum, M. C. and A. Sen (eds.): 1993, The Quality of Life (Clarendon Press, Oxford).
Paine, L. S.: 1994, 'Managing for Organizational Integrity', Harvard Business Review March-April, pp. 106-117.

Petrick, J. A. and J. F. Quinn: 2001, 'The Challenge of Leadership Accountability for Integrity Capacity as a Strategic Asset', Journal of Business Ethics 34, 331-343.

Porter, M. E. and M. R. Kramer: 2006, 'Strategy \& Society. The Link Between Competitive Advantage and Corporate Social Responsibility', Harvard Business Review, December, pp. 78-92.

Post, J. E., L. E. Preston and S. Sachs: 2002, Redefining the Corporation: Stakeholder Management and Organizational Wealth (Stanford University Press, Stanford, CA).

Prahalad, C. K.: 2005, The Fortune at the Bottom of the Pyramid: Eradicating Poverty Through Profits (Wharton School Publishing, Upper Saddle River, NJ).

Rangan, V. K., J. A. Quelch, G. Herrero and B. Barton (eds.): 2007, Business Solutions for the Global Poor (Jossey-Bass, San Francisco, CA).

Scherer, A. G. and G. Palazzo: 2007, 'Toward a Political Conception of Corporate Responsibility: Business and Society seen from a Habermasian Perspective', Academy of Management Review 32(4), 1096-1120.

Sethi, S. P.: 1975, 'Dimensions of Corporate Social Performance: An Analytical Framework', California Management Review 17(3), 58-64.

Solomon, R. C.: 1993, Ethics and Excellence. Cooperation and Integrity in Business (Oxford University Press, New York/Oxford).

Solomon, R. C.: 1999, A Better Way to Think About Business. How Personal Integrity Leads to Corporate Success (Oxford University Press, New York/Oxford).

Srivastva, S. and Associates (eds.): 1988, Executive Integrity. The Search for High Human Values in Organizational Life (Jossey-Bass, San Francisco, CA/London).

Steiner, G. A.: 1971, Business and Society (Random House, New York).

Thorne LeClair, D., O. C. Ferrell and J. P. Fraedrich: 1998, Integrity Management (University of Tampa Press, Tampa, FL).

Ulrich, P.: 1997, Integrative Wirtschaftsethik (Haupt: Bern/ Stuttgart/Vienna).

Ulrich, P.: 2008, Integrative Economic Ethics (Cambridge University Press, Cambridge) (forthcoming).

Velasquez, M.: 1983, 'Why Corporations are not Responsible for Anything They Do', Business $\mathcal{E}$ Professional Ethics Journal 2(3), 1-18.

Velasquez, M.: 2002, Business Ethics. Concepts and Cases (Prentice Hall, Upper Saddle River, NJ).

Vogel, D.: 2006, The Market for Virtue. The Potential and Limits of Corporate Social Responsibility (Brookings, Washington, DC). 
Watson, C. E.: 1991, Managing with Integrity. Insights from America's CEOs (Praeger, New York/Westport, CT/ London).

Wheeler, D. and M. Sillanpää: 1997, The Stakeholder Corporation (Pitman Publishing, London).

Wood, D. J., J. M. Logsdon, P. G. Lewellyn and K. Davenport: 2006, Global Business Citizenship. A Transformative Framework for Ethics and Sustainable Capitalism (M.E. Sharpe, Armonk, NY/London).
INSEAD \& University of St. Gallen, Institute for Business Ethics, Guisanstrasse 11, CH-9010, St. Gallen, Switzerland E-mail: thomas.maak@unisg.ch 